\title{
Role of debris cover to control specific ablation of adjoining Batal and Sutri Dhaka glaciers in Chandra Basin (Himachal Pradesh) during peak ablation season
}

\author{
Parmanand Sharma ${ }^{1, *}$, Lavkush K Patel ${ }^{1}$, Rasik Ravindra $^{2}$, Ajit Singh $^{1}$, \\ Mahalinganathan $\mathrm{K}^{1}$ and Meloth Thamban ${ }^{1}$ \\ ${ }^{1}$ ESSO-National Centre for Antarctic and Ocean Research, Ministry of Earth Sciences, Headland Sada, \\ Vasco-da-Gama, Goa 403 804, India. \\ ${ }^{2}$ Earth System Science Organization, Ministry of Earth Sciences (Government of India), Prithvi Bhawan, \\ Lodhi Road, New Delhi 110 003, India. \\ ${ }^{*}$ Corresponding author.e-mail: pnsharma@ncaor.gov.in
}

As part of the on-going annual mass balance measurements on Batal and Sutri Dhaka glaciers, observations were made during peak ablation (August-September) season in 2013 to understand the response of debris covered and clean-ice (debris free) glacier surface to melting processes. Though, both the Batal and Sutri Dhaka glaciers have almost similar geographical disposition, Batal shows extensive debris cover (90\% of the ablation area), while the latter is free from debris (only $5 \%$ of the ablation area). The thickness of debris in Batal glacier is inversely proportional to altitude, whereas Sutri Dhaka mostly experienced debris-free zone except snout area. Observation revealed that the vertical gradient of ablation rate in ablation area is contrastingly opposite in these two glaciers, reflecting significant control of debris thickness and their distribution over glacier surface on the ablation rates. While different thickness $(2-100 \mathrm{~cm})$ of debris have attenuated melting rates up to $70 \%$ of total melting, debris cover of $<2 \mathrm{~cm}$ thickness has accelerated melting up to $10 \%$ of the total melting. Estimated melt ratio reveals that about $90 \%$ of the ablation area has experienced inhibited melting in Batal glacier, whereas only less than 5\% ablation area of Sutri Dhaka has undergone inhibited melting. Comparison of topographical maps of 1962 with successive satellite images of the area demonstrates a terminus retreat of $373 \pm 33.5 \mathrm{~m}$ and $579 \pm 33.5 \mathrm{~m}$ for Batal and Sutri Dhaka glaciers for the period 1962-2013, respectively.

\section{Introduction}

The east-west trending Hindukush-Himalayan mountain chain that runs over several Asian countries is home to the largest ice mass outside the Polar regions. It covers $37 \times 10^{3} \mathrm{~km}^{2}$ area out of $540 \times 10^{3} \mathrm{~km}^{2}$ area of mountain glaciers worldwide (Dyurgerov and Meier 2005; Rai and Gurung 2005; Raina and Srivastava 2008) and has a critical impact on the socio-economic development of the region (Barnett et al. 2005; Wagnon et al. 2007).
The response of glaciers fluctuations to the climate change is complex and also depends on non-climatic factors such as the geographical extent, topography, glacial geomorphology, ice dynamics and debris cover (Racoviteanu et al. 2008). Debris covered glaciers are common in many mountain regions of the world (Scherler et al. 2011), including the Himalayas. In Himalayas, for some glaciers, almost $40 \%$ of the ablation zone is covered by debris, with thickness ranging from few centimetres to tens of centimetres that play a significant role in ablation

Keywords. Specific ablation; mass balance; debris cover; western Himalaya. 
rate and mass balance (Ogilvie 1904; Østrem 1959). The role of the supra-glacial debris cover over surface ice melt has been a subject of extensive studies. Various studies (Østrem 1959; Takeuchi et al. 2000; Bishop et al. 2001; Taschner and Ranzi 2002; Brock et al. 2007; Buchroithner and Bolch 2007; Bolch et al. 2008; Kamp et al. 2011; Scherler et al. 2011) have been carried out to understand the role of supra-glacial debris on ice melt. Some attempts have also been made to map debris covered glaciers using satellite imagery (Paul et al. 2004; Shukla et al. 2009), to determine thickness of the supraglacial debris (Mihalcea et al. 2008; Foster 2010) and to study the influence of debris cover on glacier retreat (Basnett et al. 2013). Several other studies have attempted to include debris cover into glacier melt parameterisations with different degrees of sophistication (Konovalov 2000; Reid and Brock 2010) but the Himalayan glaciers have received limited attention (Dobhal et al. 2013). These studies confirm that ice melt is enhanced by a very thin layer of supra-glacial debris as compared to thicker debris cover which reduces melt due to various factors including the thermal properties of the supra-glacial debris cover. Studies have also shown that supra-glacial debris significantly influence the terminus dynamics and modify a glacier's response to climate change (Scherler et al. 2011). Here, we attempt to integrate direct field glaciological measurements and meteorological observations to quantify the specific ablation at different altitudes from two distinct glaciers located in the same climatic zone of Upper Chandra basin during peak ablation season for evaluating the role of the debris cover on the ice melt.

\section{Study area}

The present study area of Batal $\left(32^{\circ} 20^{\prime} 29^{\prime \prime} \mathrm{N}\right.$ and $\left.77^{\circ} 34^{\prime} 57^{\prime \prime} \mathrm{E}\right)$ and Sutri Dhaka $\left(32^{\circ} 22^{\prime} 49^{\prime \prime} \mathrm{N}\right.$ and $\left.77^{\circ} 32^{\prime} 05^{\prime \prime} \mathrm{E}\right)$ glaciers lie in Chandra basin of the Western Himalaya, within the central crystalline axis of the Pir Panjal range in the western part of the Lahaul-Spiti valley of Himachal Pradesh. The Batal (IN 5Q212 12 054*) and Sutri Dhaka (IN 5Q 21212 058*) glaciers (Sangewar and Shukla 2009) are among some of the important valley glaciers in the Chandra basin that feed the Chandra River-a major tributary of the Chenab river system (see table 1). There are 205 glaciers in the Chandra basin, covering an area of $703.6 \mathrm{~km}^{2}$, which constitutes $29.5 \%$ of total basin area (Sangewar and Shukla 2009). Both the glaciers trend from southwest to northeast but the main valleys face northeast (figure 1). The area of the Batal and the Sutri Dhaka glaciers are approximately 4.9 and $25.2 \mathrm{~km}^{2}$ with total catchment area of the glacier basins being 16 and $42 \mathrm{~km}^{2}$, respectively (table 1 ). The Batal glacier is $6.6 \mathrm{~km}$ long including $2.6 \mathrm{~km}$ of accumulation zone and $4 \mathrm{~km}$ ablation zone, whereas the Sutri Dhaka glacier is $11 \mathrm{~km}$ long with $2.1 \mathrm{~km}$ of accumulation zone and $8.9 \mathrm{~km}$ ablation zone. The mean ice depths of the Batal and the Sutri Dhaka laciers are estimated to be approximately 30 and $100 \mathrm{~m}$ with total ice volume of 0.15 and $2.5 \mathrm{~km}^{3}$, respectively (Sangewar and Shukla 2009). Geomorphologically, the area represents a highly rugged, inaccessible terrain with high mountains and deeply dissected valleys. The rocks exposed on either side of the valley have been classified under Batal and Kunzamata Formation of Haimanta Group (Cambrian) (Parasher 1990; Parasher and Raj 1988; Parasher and Rapa 1981; Bhargava and Srivastava 1982). There are high ridges of moraine deposits on both sides of the glaciers. The melt runoff from Batal glacier joins the Chandra river about $1.5 \mathrm{~km}$ down-stream from snout $(1 \mathrm{~km}$ upstream from the Batal Bridge). However, the melt runoff from the Sutri Dhaka glacier joins the Chandra river about $3.5 \mathrm{~km}$ downstream from snout. While the Upper

Table 1. Characteristics of Sutri Dhaka and Batal glaciers.

\begin{tabular}{lll}
\hline Particulars & Sutri Dhaka glacier & \multicolumn{1}{c}{ Batal glacier } \\
\hline Identification number & IN 5Q 212 $12 \underline{058^{*}}$ & IN 5Q 212 $12 \underline{054}^{*}$ \\
Latitude & $32^{\circ} 22^{\prime} 49^{\prime \prime} \mathrm{N}$ & $32^{\circ} 20^{\prime} 29^{\prime \prime} \mathrm{N}$ \\
Longitude & $77^{\circ} 32^{\prime} 05^{\prime \prime} \mathrm{E}$ & $77^{\circ} 34^{\prime} 57^{\prime \prime} \mathrm{E}$ \\
Maximum elevation & $6200 \mathrm{~m}$ amsl & $6200 \mathrm{~m} \mathrm{amsl}$ \\
Snout elevation & $4400 \mathrm{~m}$ amsl & $4280 \mathrm{~m}$ amsl \\
Basin area & $42 \mathrm{~km}^{2}$ & $16 \mathrm{~km}^{2}$ \\
Glacier area & $25.24 \mathrm{~km}^{2}$ & $4.92 \mathrm{~km}^{2}$ \\
Glacier length & $11 \mathrm{~km}$ & $6.60 \mathrm{~km}^{2}$ \\
Orientation & Accu.-N/Ablat.-NE & Accu.-NE/Ablat-NE \\
Mean depth & $100 \mathrm{~m}$ & $30 \mathrm{~m}$ \\
Volume & $2.53 \mathrm{~km}$ & $0.15 \mathrm{~km}^{3}$ \\
Accumulation area ratio (AAR) & $56 \%$ & $61 \%$ \\
\hline
\end{tabular}

${ }^{*}$ These are the numbers given to each of the glaciers of Indian part of Himalaya by Geological Survey of India (GSI) inventory (Sangewar and Sukla 2009). 


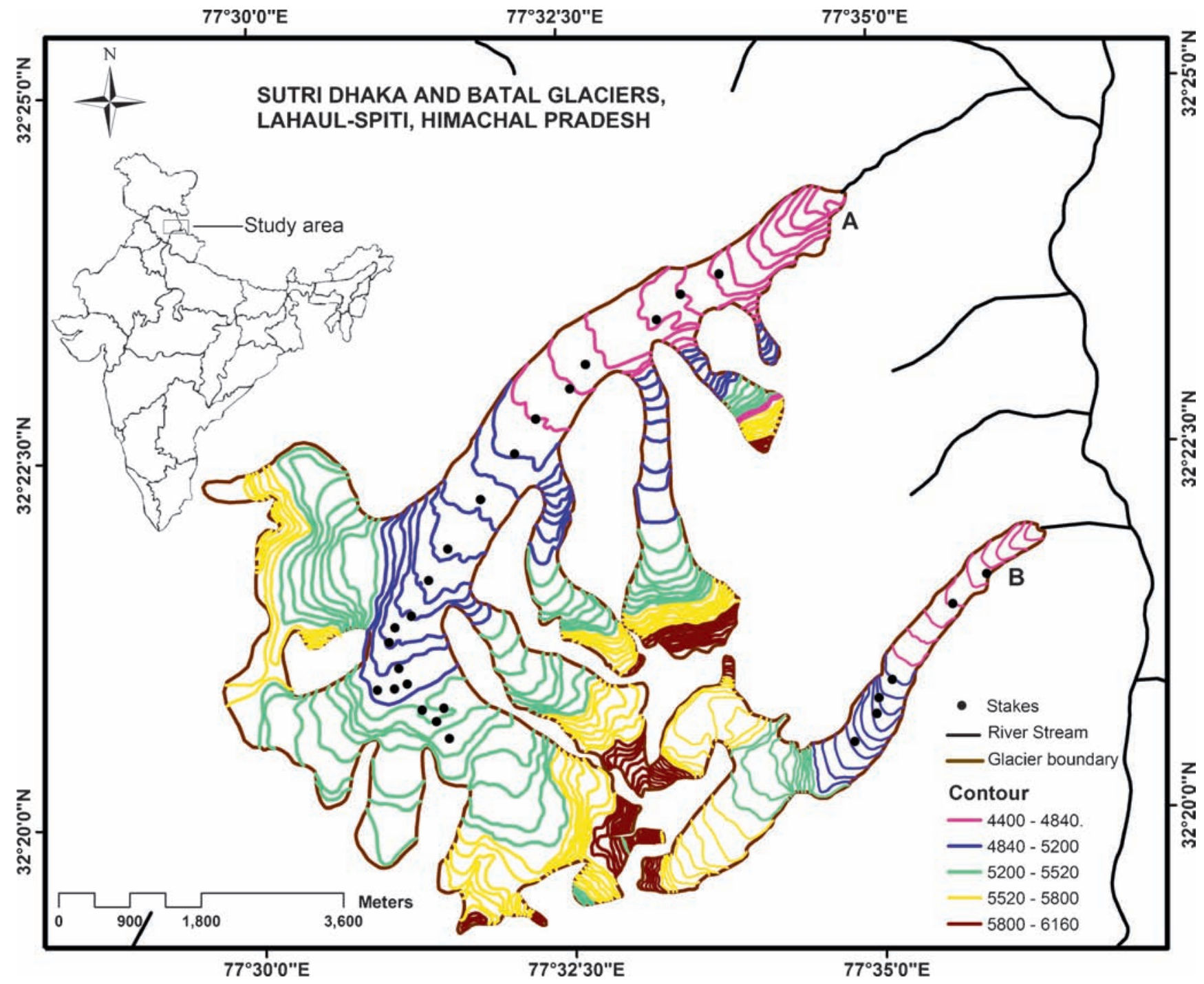

Figure 1. Map of study area showing the location of Sutri Dhaka and the Batal glaciers in Lahaul-Spiti valley of Chandra river basin in Himachal Pradesh, India.

Chandra valley has a general slope of $25^{\circ}-40^{\circ}$, the average channel slope of the Batal and the Sutri Dhaka glaciers are approximately $17^{\circ}$ and $10^{\circ}$, respectively. The snout of the Batal and the Sutri Dhaka glaciers are located at an altitude of 4280 and $4400 \mathrm{~m}$ amsl, respectively (toposheets $52 \mathrm{H} / 11$ $\& 52 \mathrm{H} / 7$ from Survey of India; 1:50,000 scale; surveyed in 1962). However, for the present, the snout location of the Batal and the Sutri Dhaka are at 4302 and $4480 \mathrm{~m}$ amsl (GPS survey during 2013 field), respectively. The permanent snow line is above $5000 \mathrm{~m}$ for both the glaciers and the accumulation zone of the glaciers extends up to $6200 \mathrm{~m}$. Both the glaciers are near the northern limit of South Asian monsoon influence zone and experience two distinct precipitation regimes (Bookhagen and Burbank 2006). Most of the precipitation occurs in summer (July-September) due to the Southwest monsoon, while there is also significant amount of precipitation in late winter (January-April) due to the mid-latitude western disturbances (figure 2). This area is characterized by fairly cold temperatures, heavy and dry snowfall with strong wind action (Sharma and Ganju 2000; Negi et al. 2013). The short-term meteorological observations (AugustSeptember 2013) on the glacier collected during study period showed temperatures ranging from $-6.8^{\circ} \mathrm{C}$ to $+18.6^{\circ} \mathrm{C}$ at $4000 \mathrm{~m}$ amsl near the base camp.

\section{Methodology}

As part of the long term programme entitled 'Cryosphere and Climate', National Centre for Antarctic and Ocean Research (NCAOR) has initiated glaciological monitoring on the Batal and the Sutri Dhaka glaciers in the Chandra basin. Since $90 \%$ of the ablation area of Batal glacier was covered by debris, it may be described as a 


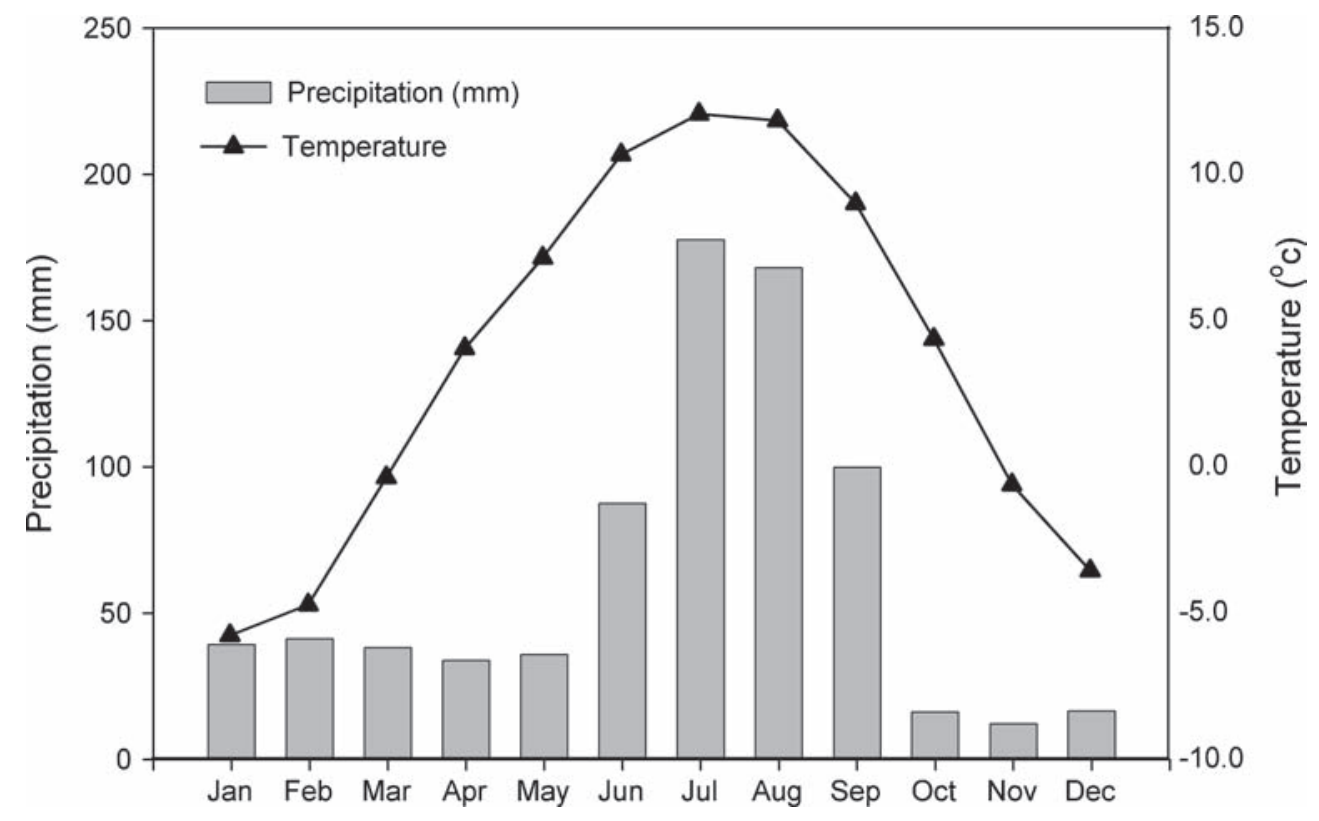

Figure 2. Mean annual cycle (over 102 years, 1901-2002) of monthly precipitation and of monthly temperature in LahaulSpiti region (www.indiawaterportal.org, data from water portal of Government of India, 2013).

debris-mantled or D-type glacier (Benn and Owen 2002). However, the Sutri Dhaka glacier has only $5 \%$ of the ablation area covered by debris and is called as a clean glacier or C-type glacier. Measurements were taken during peak ablation season (August-September, 2013) to understand the diurnal and seasonal specific ablation and the role of debris on the rate of ablation. The methodology adopted for measurements, mapping and analysis including estimation of uncertainty are given below.

\subsection{Analysis of specific ablation}

We have used the direct glaciological method (Østrem and Brugman 1991; Paterson 1994) to calculate the mass balance and the specific ablation. In practice, the measured accumulation or ablation is integral of accumulation rate and ablation rate with respect to time interval $\left(t_{0}, t_{1}\right)$. In the ablation area of both the glaciers, the specific mass balance was determined by a network of well distributed stakes installed in ice deep down to 10 $12 \mathrm{~m}$. Twenty-three ablation stakes (21 in ablation zone and two in the transition zone of ablation and accumulation zone) were fixed between 4200 and $5500 \mathrm{~m}$ amsl in the Sutri Dhaka glacier, while in the Batal, six stakes (ablation zone) were fixed between 4200 and $4800 \mathrm{~m}$ amsl along the flow line (figure 1). Among 23 ablation stakes, only 17 stakes were monitored in the Sutri Dhaka due to easy accessibility during observation period. All the representative stakes were installed over debris covered area in Batal glacier and clean ice (debris free) area in Sutri Dhaka glacier. No stakes were installed above
$4800 \mathrm{~m}$ in Batal due to inaccessibility (crevasses and avalanche prone zone with vertical ice/rock column). The length of the stakes $(L)$ from the surface (ice surface) was measured at two successive dates $\left(t_{0}, t_{1}\right)$ during observation period. The depth of snow over the ice surface was also measured. The difference between exposed stakes length at $t_{0}$ and $\mathrm{t}_{1}$ plus difference of snow depth at $t_{0}$ and $t_{1}$, gives the specific ablation or accumulation at respective points. Since the density of ice and snow are different, specific ablation was calculated in terms of water equivalent (we). Specific ablation ( $\mathrm{cm}$ we) of each stake was calculated using the following equation

$$
\begin{aligned}
& \text { Specific ablation (cm we) } \\
& \qquad=\left(L_{t_{1}}-L_{t_{0}}\right) * \rho_{i}+\left(S_{t_{1}}-S_{t_{0}}\right) * \rho_{s}
\end{aligned}
$$

where $\rho_{i}$ is the density of ice (assumed $0.9 \mathrm{~g} / \mathrm{cm}^{3}$ ) and $\rho_{s}$ is the density of snow. Snow was almost absent in the ablation zone during the observation period except at few points. Ice density was taken as a constant $\left(0.9 \mathrm{gcm}^{3}\right)$. However, snow density was measured systematically as mentioned below. At first, snow depth was measured using snow probe and pits. The snow pits were made manually and the dimension of pits were dug based on snow depth. Snow samples were collected along the depth of the pits with the help of a steel cylinder of known length and diameter $(20.5 \mathrm{~cm}$ length and $5.64 \mathrm{~cm}$ of inner diameter for this study). Further, the snow samples were transferred into a pre-weighted plastic bag and weighed it using a sensitive balance. To avoid the errors in the measurement, balance was 
kept away from the influence of wind in the field. The density of the snow was calculated by using the following formula:

$$
\rho=\frac{M}{V}
$$

where $\rho$ is density of snow, $M$ is the mass of snow and $V$ is the volume of cylinder.

The overall specific balance, $b_{n}$, is calculated according to Paterson (1994),

$$
b_{n}=\Sigma b_{i} \Delta S_{i}
$$

where $b_{n}$ is the specific balance of the altitudinal range, $i$, of the map area $S_{i}$ and $S$ is the total glacier map area $\left(S=\Sigma \Delta S_{i}\right)$. For each altitudinal range, $b_{i}$ is obtained from the corresponding stake readings or net ablation/accumulation measurements. The hypsography of the glacier is derived from a composite topography. This topography was obtained by combining Survey of India Toposheet $(52 \mathrm{H} / 7$ and $52 \mathrm{H} / 11)$ of 1962 on scale of $1: 50,000$ with $40 \mathrm{~m}$ contour interval (planimetric accuracy $\pm 12.5 \mathrm{~m}$ and elevation accuracy $\pm 6.5 \mathrm{~m}$ ) and ASTER GDEM 2 (2009). The planimetry and elevation accuracy were calculated by using six ground control points (GCPs) in the study area and comparing these GCPs coordinates (surveyed by differential GPS) to respective points on SOI toposheets. Using a single map over the whole measuring period to derive $b_{n}$ means that we obtain the referencesurface glacier-wide balance (Harrison et al. 2005) to calculate specific mass balance. Accuracy of this overall specific balance depends on various factors such as the accuracy of stake readings and the density measurements, representativeness of stakes and the accuracy of map. Though, the accuracy of $b_{n}$ cannot be strictly evaluated, it is presumed to be approximately $\pm 20 \%\left( \pm 20 \mathrm{~cm}\right.$ we $\mathrm{a}^{-1}$ for 100 $\mathrm{cm}$ we $\left.\mathrm{a}^{-1}\right)$, a typical error range for mass balance data (Jansson 1999).

To understand the role of debris cover on specific ablation, stakes were installed at the same altitude on debris-covered and debris-free ice surfaces of both the glaciers. Apart from stakes, extensive in situ surveys of debris thickness were conducted
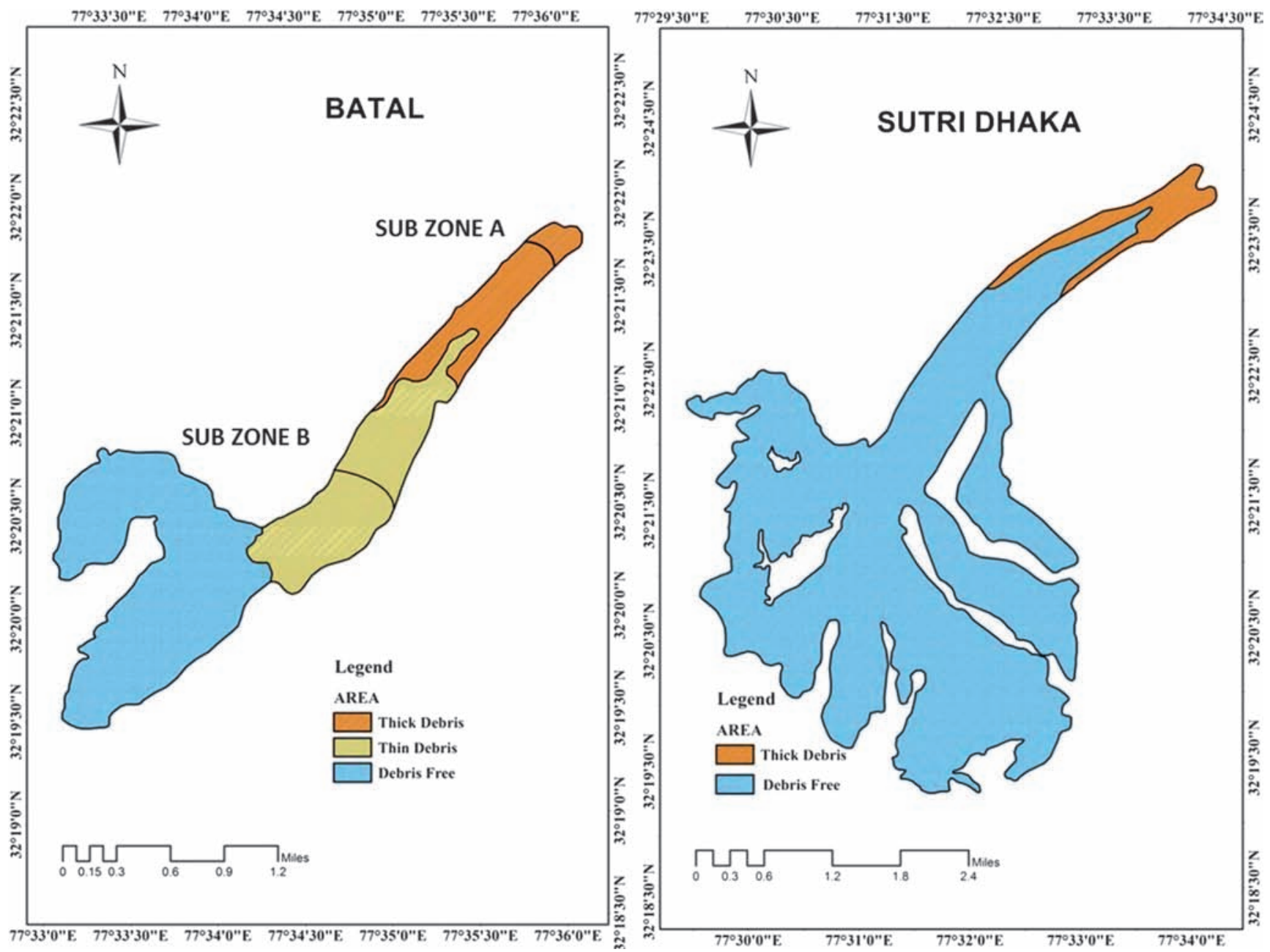

Figure 3. Distribution of debris covers over surface of the Batal and the Sutri Dhaka glaciers. 
across the altitudinal range in two glaciers including various glacier tables (boulders over ice) to validate the impact. The debris cover was removed manually at more than 42 sites up to the ice-debris contact to measure the thickness of debris cover. The colour coding and spatial distribution of debris thickness are shown in figures 3 and 4, respectively. The ablation rate was monitored at six stakes and 10 ice tables in Batal and at 17 stakes on Sutri Dhaka glaciers. Using these data, two transverse profiles (figure 3 ), one at the lower ablation and the other at upper ablation, were created across the representative areas of the glaciers. Each profile (sub-zone) was drawn by using several points' data of debris thickness. The annual monitoring of glacier terminus position, area loss, surface volume loss and elevation change was calculated using well established techniques (Østrem and Brugman 1991; Dobhal et al. 2004, 2008).

\subsection{Glacier mapping and analysis}

The data sources and their characteristics utilized for different purposes in this paper are given in table 2. Landsat 8, 7 and 5 satellites data of Operational Land Imager (OLI), Enhanced Thematic Mapper Plus (ETM+), Thematic Mapper (TM) sensors and ASTER GDEM 2 data were used for the glacier features extraction. The Landsat datasets were obtained from the United State Geological Survey (USGS) website (http://earthexplorer. usgs.gov/) and ASTER GDEM 2 was downloaded from http://www.ersdac.or.jp/. SOI toposheets map of $1962(52 \mathrm{H} / 10$ and $\mathrm{H} / 11 ; 1: 50,000)$ were used as a reference for the identification and interpretation of glaciers in the Landsat imagery. Pan sharpening algorithm (Brovery transform algorithm with bilinear interpolation re-sampling method) was used to enhance the quality and spatial resolution of Landsat data (ETM ${ }^{+}$and OLI). Landsat OLI 2013 image was used as the base to geo-reference all satellite data with minimum registration error ( 0.5 pixel) in UTM Zone 44 North projection, WGS-84 datum. Many researchers have used various remote sensing techniques such as unsupervised classification, supervised classification, ratio images, and NDSI for the delineation of clean and debris covered glaciers (Gratton et al. 1990; Aniya et al. 1996; Sidjak and Wheate 1999;

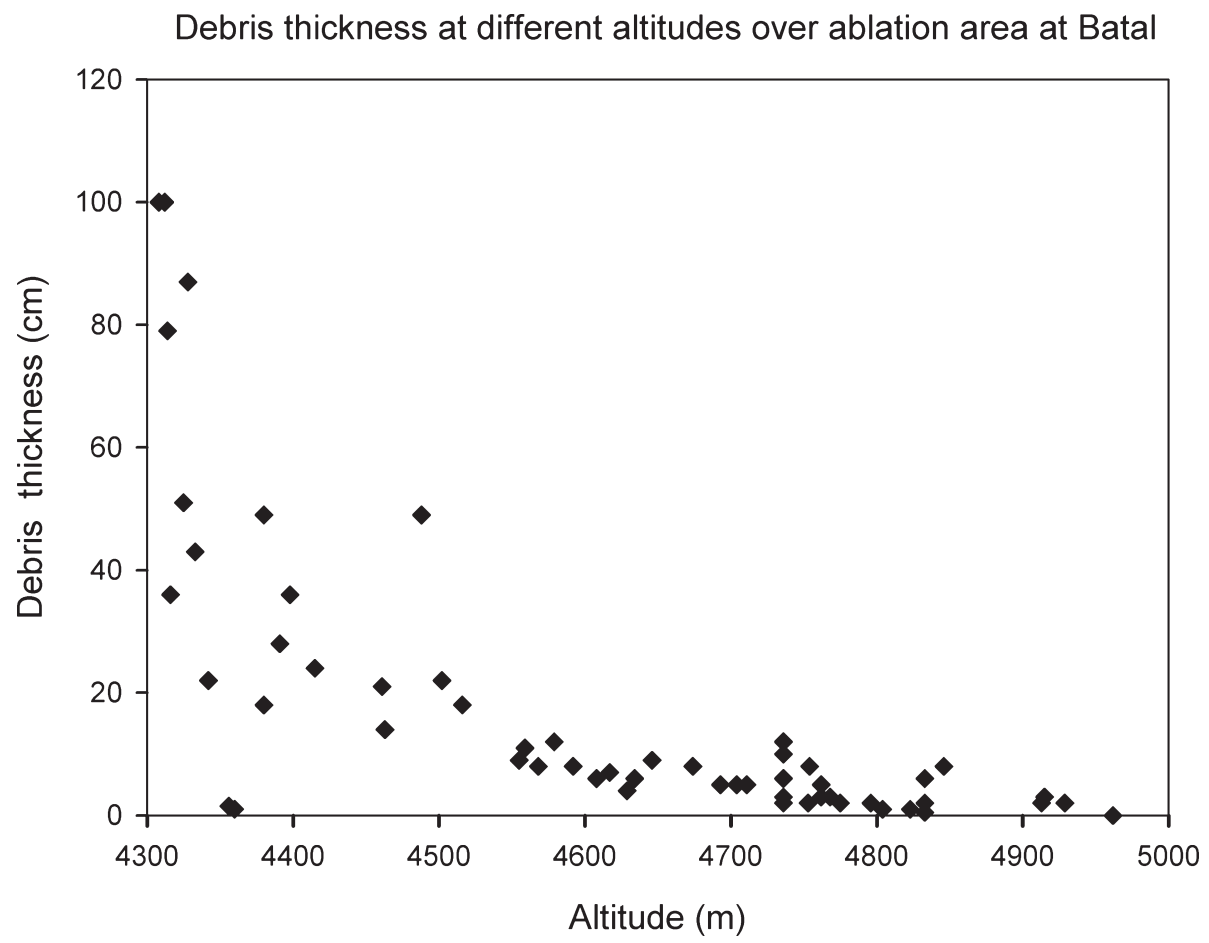

Figure 4. Variations in thickness of debris with altitude in the Batal glacier.

Table 2. Satellite data used and their characteristics.

\begin{tabular}{lllrcr}
\hline Date of pass & \multicolumn{1}{c}{ Scene ID } & Satellite/sensor & Bands & Resolution (m) & RMSE (pixel) \\
\hline $2013 / 10 / 27$ & LC81470382013204LGN00 & Landsat 8 OLI & 14 & $30 / 15(\mathrm{PAN})$ & 0.4 \\
$2000 / 10 / 15$ & LE71470382000289SG00 & Landsat 7 ETM & 8 & $30 / 15(\mathrm{PAN})$ & 0.5 \\
$1989 / 10 / 09$ & p147r38_5t19891009 & Landsat 5 TM & 7 & 30 & 0.5 \\
\hline
\end{tabular}


Racoviteanu et al. 2008; Paul et al. 2009). Since the above techniques are suitable for larger coverage area, manual extraction is one of the best techniques to delineate small coverage area (Pandey and Venkataraman 2013). Since our study area together covers a small area $\left(30 \mathrm{~km}^{2}\right)$ and is surveyed extensively, manual digitization technique is one of the best suited technique for this study. Glacier boundaries for each year were extracted manually from the data of OLI (pan sharpened), and $\mathrm{ETM}^{+}$and Thematic Mapper (TM). Visual interpretation techniques considering various parameters such as terminus shadow, shape (convex and concave) and reflectance (debris and debris free) were used to delineate the terminus of the Batal and the Sutri Dhaka glaciers. Upper boundaries of the glaciers were fixed and it was assumed that they did not change over the studied period. Debris cover was manually extracted from the Landsat OLI 2013 image. In the OLI satellite data, the lower terminus and the edges were validated from collected GCPs $( \pm 3 \mathrm{~m})$ and debris upper boundary were digitized separately from clean ice based on unique reflectance of debris cover. GPS measurements during 2013 were used for validation of terminus position and debris extent in OLI image. Glacier ice in the ablation area has substantially lower reflectance than snow in the accumulation area, but higher than that of rock and soil of the surrounding area. The nonglacier area present in front of the glacier snout exhibiting bright tone with fine texture in contrast to coarse and mottled texture over glacier surface helped in the delineation of glacier lower limits (Pandey et al. 2011). RGB and NIR, R and G false colour composites were used for better delineation of glaciers features in TM data. The decadal glacier boundaries for each year (1962, 1989, 2000 and 2013) were extracted from the satellite data and SOI toposheet and glacier terminus altitude for each year extracted from the ASTER GDEM V2 (to avoid additional error).

\subsection{Uncertainty estimation}

Uncertainty in glacier terminus and area loss was estimated using the following formula (Hall et al. 2003; Bhambri et al. 2012).

$$
e=\sqrt{a^{2}+b^{2}}+E
$$

where $a$ and $b$ represent the spatial resolution of the two images used, and $E$ is the co-registration error. The uncertainty for the glacier area was estimated by multiplication of the uncertainty of length and glacier width (Bhambhri et al. 2012). Uncertainty in SOI data (planemetric error $\pm 12.5 \mathrm{~m}$ ) was added with the subsequent year satellite data uncertainty.
The uncertainties for the changes in terminus of both the glaciers are $57.5 \mathrm{~m}$ for 1962-1989, $41 \mathrm{~m}$ for 1989-2000 and $27 \mathrm{~m}$ for 2000-2013; however, it is $33.5 \mathrm{~m}$ for $1962-2013$. Uncertainties in the glacier area of Batal are 0.02, 0.02 and $0.01 \mathrm{~km}^{2}$ for year 1962-1989, 1989-2000, 2000-2013, respectively; however for the overall period of 1962-2013, it is $0.02 \mathrm{~km}^{2}$. Similarly, for the Sutri Dhaka glacier, the uncertainty in the area loss are 0.05, 0.04 and $0.02 \mathrm{~km}^{2}$ for the period $1962-1989,1989-2000$ and 2000-2013, respectively, whereas it is $0.03 \mathrm{~km}^{2}$ for the overall period of 1962-2013. The uncertainty in vertical shifting is $17 \mathrm{~m}$ adopted as per the accuracy of the ASTER GDEM V2 (ASTER GDEM Validation Team 2011; Worni et al. 2013).

\section{Results and discussion}

\subsection{Spatial distribution of debris over the Batal and the Sutri Dhaka glaciers}

The spatial distribution of debris cover over both the glaciers is shown in figure 3. Further, the distribution of debris thickness at different elevations in the ablation zone over the Batal glacier is depicted in figure 4. However, the measurement techniques involved in debris thickness calculations are shown in figure 5. It is observed that the general trend of debris thickness is decreasing with increasing altitude in the ablation zone. However, in some areas the spatial distribution is inhomogeneous due to the presence of crevasses, supra-glacial ponds and ice cliffs. In Batal glacier, debris of varying thickness cover more than $90 \%$ of total ablation area, while in Sutri Dhaka glacier it is less than $5 \%$ of the ablation area. Accumulation area in both the glaciers is free from debris. Field observation data indicate that the debris thickness increases from a few centimetres over upper ablation zone to hundreds of centimetres at or near the terminus (figure 4). The variation in debris thickness is pronounced in the lower ablation zone, whereas it is subdued in the upper ablation zone. At the lower ablation zone at sub-zone $\mathrm{A}$, debris cover is much thicker at the southern and northern lateral margins of the glacier than in the central part. However, in the upper ablation zone, debris cover is thick near the lateral margin of both sides. Further, debris thickness subsequently decrease towards the central part and after $50 \mathrm{~m}$ from each lateral margin again show gradual increase in debris thickness. Detailed field surveys for measuring debris thickness on glaciers was undertaken at 42 sites, excluding the sites where drilling was done to install the stakes. The transverse profile at the upper ablation zone (subzone B) showed an increasing trend towards the lateral margin. For the lower ablation zone (sub-zone 

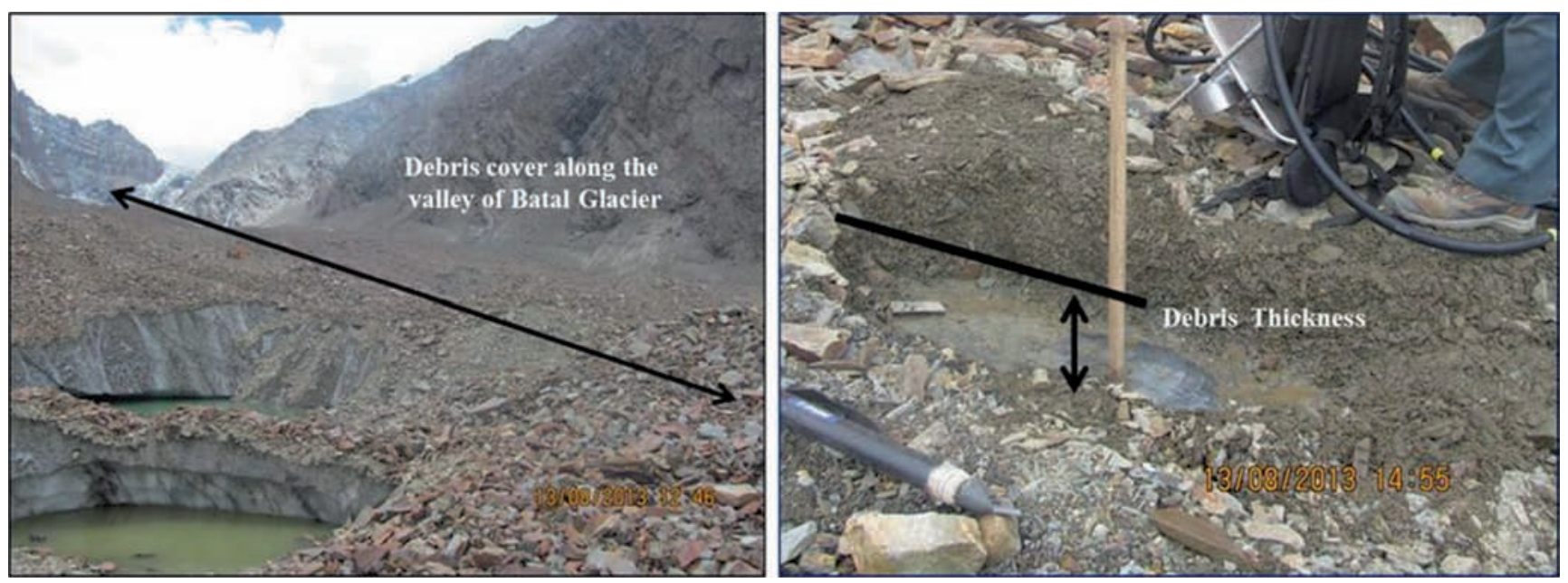

Figure 5. Field photographs showing in situ observation of debris cover and manual measurements of debris thickness.

A), the variation in thickness was pronounced due to the heterogeneous distribution of debris thickness, which varied from a few centimetres to $>1$ $m$. In contrast, variation in debris thickness was small in profile B (figure 5). A gradual increase was observed in the central downstream part of the flow line. This indicates the transition from patchy thin debris cover at higher altitudes to a thick, continuous debris cover at lower altitudes.

\subsection{Glacier terminus retreat and area loss}

The earliest data on both the glaciers were extracted from Survey of India topographic maps $(52 \mathrm{H} / 7$ and $52 \mathrm{H} / 11)$ of 1962 on scale of $1: 50,000$ with $40 \mathrm{~m}$ contour interval (planimetric accuracy $\pm 12.5 \mathrm{~m}$ and elevation accuracy $\pm 6.5 \mathrm{~m}$ ). The glacier margin or terminus, will advance or retreat depending on the glacier's recent mass balance history, which in turn could be influenced by the recent pattern of climate variations (Porter 1981). The latest terminal positions were marked during field observations in 2013. Changes in the terminus position were measured by GPS with a vertical accuracy $(\mathrm{z})$ of 1-3 $\mathrm{m}$ and a horizontal accuracy $(\mathrm{x}, \mathrm{y})$ of $3 \mathrm{~m}\left(0.01^{\prime}\right)$. The area vacated by the glaciers due to recession was estimated by comparing the field measurements with DEM and the SOI topographic map (1962). Our study reveals a terminus retreat of $373 \pm 33.5 \mathrm{~m}$ (an average of $7.3 \pm$ $0.7 \mathrm{~m} \mathrm{a}^{-1}$ ) and $579 \pm 33.5 \mathrm{~m}$ (an average of 11.4 $\left.\pm 0.7 \mathrm{~m} \mathrm{a}^{-1}\right)$ for Batal and Sutri Dhaka glaciers (figure 6), respectively, during the period 19622013. Both the glaciers have experienced retreat and mass loss during the timespan of 51 years. Interestingly, the rate of retreat is higher in case of Sutri Dhaka than that of Batal glacier. All available literature revealed that small mountain glaciers tend to respond rapidly to climate variations
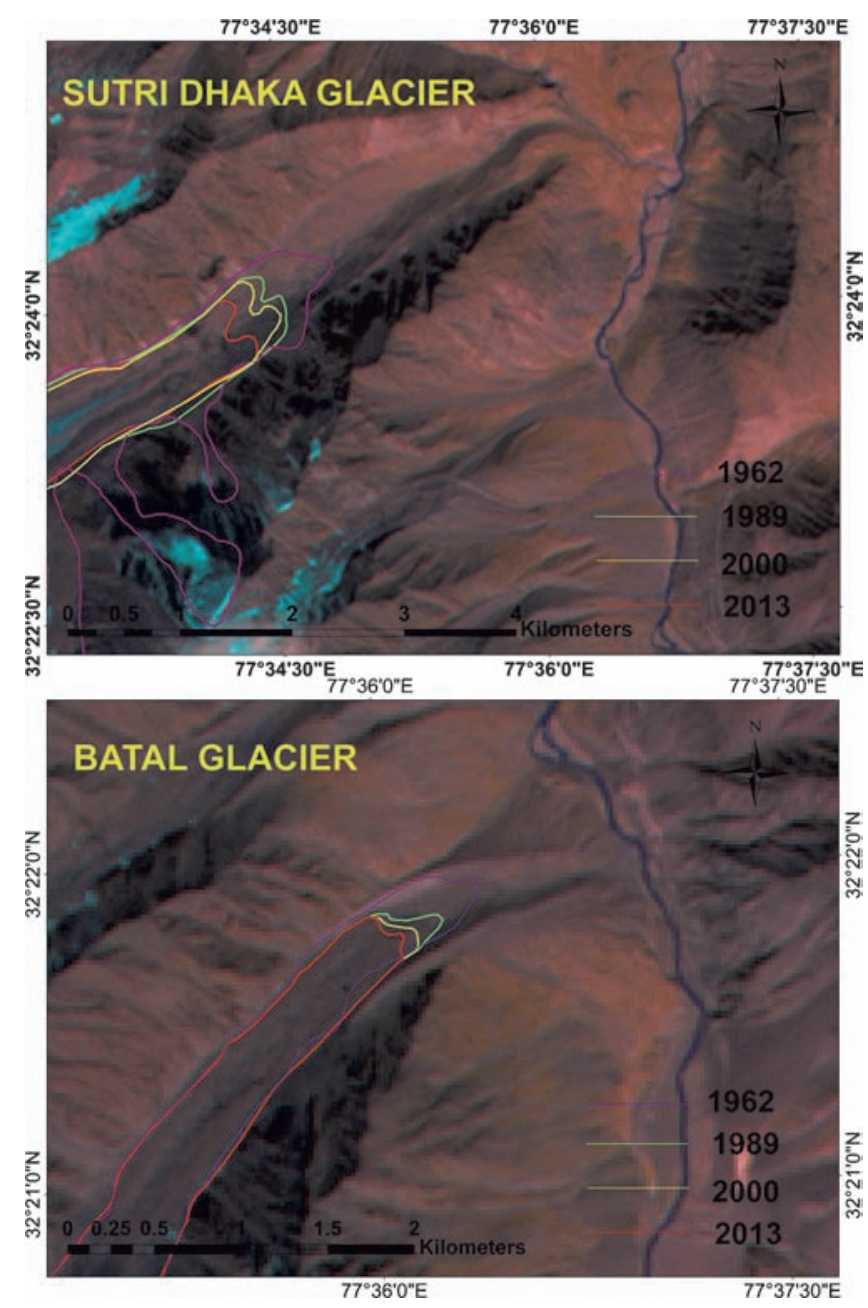

Figure 6. Terminal (snout) fluctuations at the Sutri Dhaka and the Batal glaciers since 1962, compiled from Survey of India topographic maps and various satellite images.

(Porter 1981; Burbank 1982; Pandey et al. 2013). However, our results are in contrast to the broad hypothesis postulating higher melting and retreating rates in case of smaller glaciers (Porter 1981; 
Burbank 1982; Kulkarni et al. 2007). Such contradicting result of terminus retreat of the small valley glacier Batal suggests that the glacier retreat may be significantly controlled by the integrated impact of debris cover and significant areal and temporal shadow cover (shadow of cliff on the margin) over the ablation zone. Though the snouts of the two glaciers have been retreating at varying rates, it was observed that the long-term average retreat rate for the Batal glacier has increased significantly from $7.4 \pm 2.1 \mathrm{~m} \mathrm{a}^{-1}(1962-1989)$ to $10.7 \pm 3.7 \mathrm{~m} \mathrm{a}^{-1}$ (1989-2000) and decreased again to $4.3 \pm 2.1 \mathrm{~m} \mathrm{a}^{-1}$ (2000-2013) (table 3). For the same time interval, the snout of the Sutri Dhaka glacier has experienced a totally different trend and initially shows a decreasing trend from $12.3 \pm 2.1 \mathrm{~m} \mathrm{a}^{-1}(1962-1989)$ to $8.7 \pm 3.7 \mathrm{~m} \mathrm{a}^{-1}(1989-2000)$ and subsequently the rate accelerated since the beginning of last decade to $11.8 \pm 2.1 \mathrm{~m} \mathrm{a}^{-1}(2000-2013)$. The results are similar to data obtained from one of the nearby glacier, Chhota Shigri showing zero or slightly negative mass loss during 1990-2000 and since then, an accelerated mass loss (Azam et al. 2011; Vincent et al. 2013). On a regional perspective, our results revealed that the average recession rate for the
Batal/Sutri Dhaka glaciers are lower than that of other glacier in the same region (like Bada Shigri and Samudra Tapu), with rates of recession varying between 25 and $40 \mathrm{~m} \mathrm{a}^{-1}$ and near to Chhota Shigri with rates between 6 and $7 \mathrm{~m} \mathrm{a}^{-1}$. Snout retreat rates of some of the Himalayan glaciers are given in table 4 . The highest rate of terminus retreat was experienced by Pindari glacier $\left(135 \mathrm{~m} \mathrm{a}^{-1}\right)$, while the lowest for Ponting glacier (5.1 $\mathrm{m} \mathrm{a}^{-1}$ ) (Dobhal et al. 2004; Kulkarni et al. 2005, 2007; Raina 2009; Mehta et al. 2011, 2013). The wide variation in the rate of terminus retreat is common in Himalayan glaciers and are controlled by various factors like climatic (temperature, precipitation, wind and solar radiation) and non-climatic (such as topography, debris cover, slope and spatial distribution). The area vacated by the Batal and Sutri Dhaka glaciers, were estimated by comparing SOI topographic maps and satellite data given in table 3 . The total area vacated by the Batal and Sutri Dhaka glaciers is $0.3 \pm 0.02 \mathrm{~km}^{2}$ and $3.1 \pm 0.03 \mathrm{~km}^{2}$, respectively between years 1962 and 2013. The high area loss in case of Sutri Dhaka is explained by detachment of three tributaries glaciers from the main trunk.

Table 3. Change in areal coverage of Batal and Sutri Dhaka glaciers.

\begin{tabular}{|c|c|c|c|c|c|c|c|c|c|}
\hline Glaciers & Year & $\begin{array}{c}\text { Area } \\
\left(\mathrm{km}^{2}\right)\end{array}$ & $\begin{array}{c}\% \text { Change } \\
\text { in area }\end{array}$ & $\begin{array}{c}\% \text { Change/ } \\
\text { year }\end{array}$ & $\begin{array}{c}\text { Snout } \\
\text { elevation } \\
(\mathrm{m} \text { amsl) }\end{array}$ & $\begin{array}{c}\text { Vertical } \\
\text { shifting } \\
(\mathrm{m})\end{array}$ & $\begin{array}{l}\text { Vertical } \\
\text { shifting } \\
(\mathrm{m}) / \text { year }\end{array}$ & $\begin{array}{l}\text { Average } \\
\text { Terminal } \\
\text { shift }(\mathrm{m})\end{array}$ & $\begin{array}{c}\text { Snout } \\
\text { retreat } \\
\text { (m/year) }\end{array}$ \\
\hline \multirow[t]{4}{*}{ Sutri Dhaka } & 1962 & 25.24 & & & 4391 & & & & \\
\hline & 1989 & 23.80 & 5.7 & 0.2 & 4454 & 63.0 & 2.3 & 331.0 & 12.3 \\
\hline & 2000 & 22.95 & 3.6 & 0.3 & 4470 & 16.0 & 1.5 & 95.4 & 8.7 \\
\hline & 2013 & 22.15 & 3.5 & 0.3 & 4503 & 33.0 & 2.5 & 152.8 & 11.8 \\
\hline \multirow[t]{4}{*}{ Batal } & 1962 & 4.92 & & & 4182 & & & & \\
\hline & 1989 & 4.88 & 0.8 & 0.03 & 4226 & 44.0 & 1.6 & 199.0 & 7.4 \\
\hline & 2000 & 4.73 & 3.1 & 0.3 & 4251 & 25.0 & 2.3 & 118.1 & 10.7 \\
\hline & 2013 & 4.63 & 2.1 & 0.2 & 42880 & 37.0 & 2.8 & 55.9 & 4.3 \\
\hline
\end{tabular}

Table 4. Glacier and Snout recession of some important glaciers of Indian Himalaya.

\begin{tabular}{lccc}
\hline Glacier & Period & $\begin{array}{c}\text { Retreat of } \\
\text { snout (m) }\end{array}$ & $\begin{array}{c}\text { Avg. retreat of } \\
\text { glacier (m/yr) }\end{array}$ \\
\hline Triloknath (Himachal Pradesh) & $1969-1995$ & 400 & 15.4 \\
Dokriani Bamak & $1962-1997$ & 586 & 16.8 \\
Pindari (Uttaranchal) & $1845-1966$ & 2,840 & 135.2 \\
Milam (Uttaranchal) & $1909-1984$ & 990 & 13.2 \\
Ponting (Uttaranchal) & $1906-1957$ & 262 & 5.1 \\
Chota Shigri (Himachal Pradesh) & $1986-1995$ & 60 & 6.7 \\
Chota Shigri (Himachal Pradesh) & $2002-2010$ & 49.7 & 6.2 \\
Bara Shigri (Himachal Pradesh) & $1977-1995$ & 650 & 36.1 \\
Gangotri (Uttaranchal) & $1977-1990$ & 364 & 28.0 \\
Gangotri (Uttaranchal) & $1985-2001$ & 368 & 23 \\
Zemu (Sikkim) & $1977-1984$ & 194 & 27.7 \\
\hline
\end{tabular}

Source: IPCC (2007). 


\subsection{Specific ablation as a function of altitude and its relation to debris cover}

Figure $7(\mathrm{a}$ and $\mathrm{b})$ displays the specific ablation as a function of altitude over the Batal and the Sutri Dhaka glaciers. Data reveals that the Batal glacier has an almost opposite trend of specific ablation rate than Sutri Dhaka within the ablation zone. In the Sutri Dhaka glacier, the ablation rate is inversely proportional to the altitude in ablation area, display decreasing trend of melting with increasing altitude, whereas the Batal glacier showed a positive relation of melting rate with altitude in ablation zone. In the upper Chandra basin, few of the studied glaciers like Chhota Shigri and Hamta revealed similar trend as that of the Sutri Dhaka (Sharma 2007; Wagnon et al. 2007; Vincent et al. 2013). The debris-covered area in the Batal accounted for more than $90 \%$ of the ablation area, while it was less than $5 \%$ on the Sutri Dhaka glacier. Several points over the glacier surface were monitored including the central flow line to understand the spatial characteristics of the ice melt rates influenced by debris thickness and its
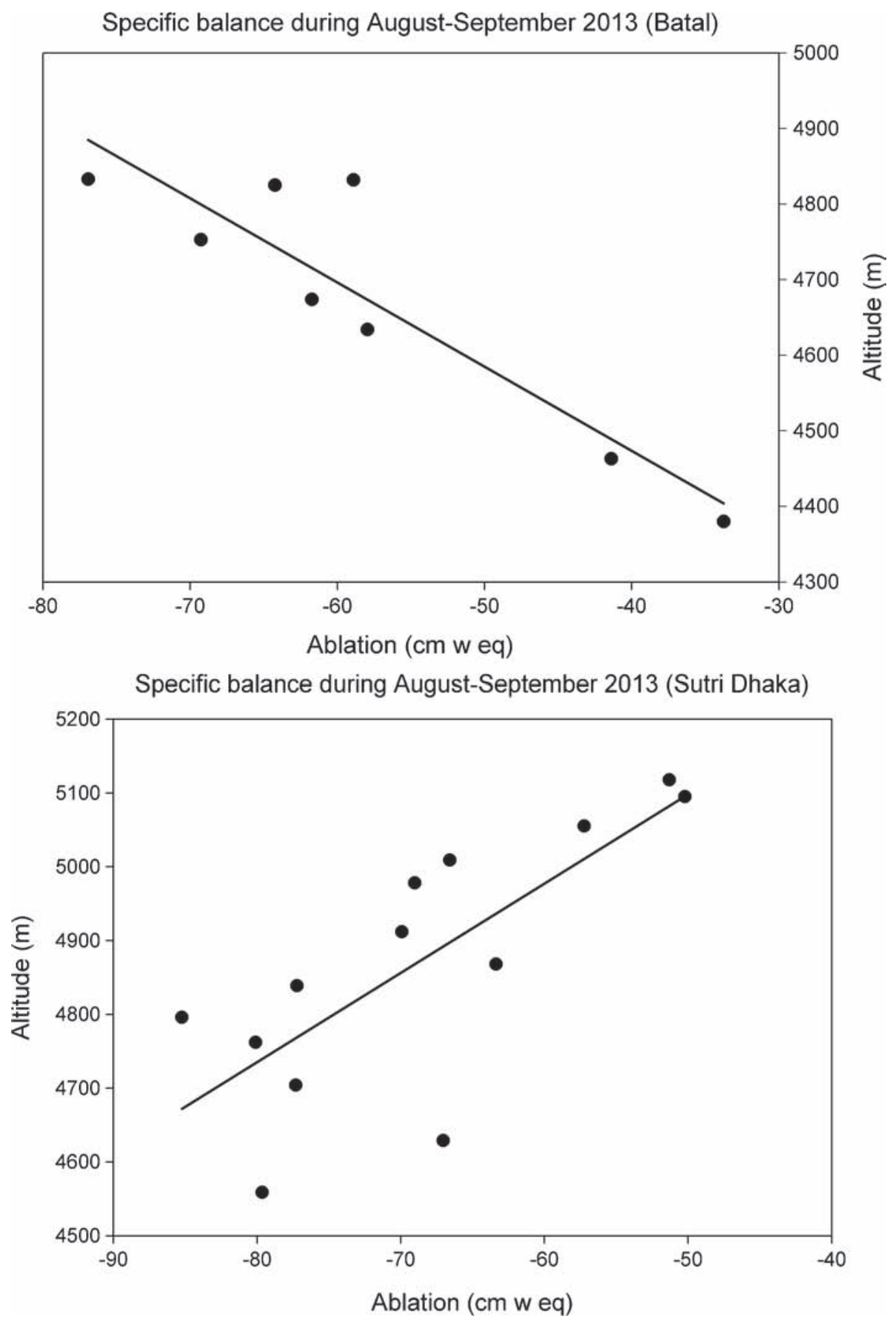

Figure 7. Specific balance during August-September 2013 of (a) Batal and (b) Sutri Dhaka ablation areas. 
spatial continuity. Apart from stakes, the ice tables were also measured randomly over the glacier surface to calculate the ablation rate in the ablation zone. Such contrasting ablation characteristics of both the glaciers suggested that a thin cover of debris may accelerate the melting, while a further increase in debris thickness may actually slow down the ablation processes. Even a debris cover of few centimetres mixed with isolated rocks protects the ice surface from melting. A maximum ablation of $-5.6 \pm 1.12 \mathrm{~cm}$ we $\mathrm{d}^{-1}$ and $-3.6 \pm 0.72 \mathrm{~cm}$ we $\mathrm{d}^{-1}$ was estimated in the Sutri Dhaka and the Batal glaciers at 4796 and $4634 \mathrm{~m}$ asl altitude, respectively. It was also observed that the mean vertical gradient of ablation is $123 \pm 23 \mathrm{~cm}$ we $100 \mathrm{~m}^{-1}$ in the Sutri Dhaka, while it is negative $(-92 \pm 18 \mathrm{~cm}$ we $100 \mathrm{~m}^{-1}$ ) over the ablation zone of the Batal glacier during the study period. The measured specific ablation rate of the Sutri Dhaka was estimated to be $2.6-4.6 \mathrm{~cm}$ we $\mathrm{d}^{-1}$ (more on the debris-free area than over the debris covered part). However, the mass balance was still negative on the debris covered area at this elevation, with values varying between 2.1 and $5.0 \mathrm{~cm}$ we $\mathrm{d}^{-1}$. The mean daily vertical gradient over Sutri Dhaka glacier is estimated to be $2 \pm 0.4 \mathrm{~cm}$ we $100 \mathrm{~m}^{-1}$ over the ablation area which is slightly smaller than vertical gradients observed in the Alps or on the mid-latitude glaciers (Rabatel et al. 2005) and much smaller than gradients measured on the tropical glaciers which can be as high as $20 \mathrm{~cm}$ we $100 \mathrm{~m}^{-1}$ (Wagnon et al. 1999; Kaser 2001). However, the mean daily vertical gradient over the Batal is inverse of the Sutri Dhaka and estimated to be $-1.2 \pm 0.24 \mathrm{~cm}$ we $100 \mathrm{~m}^{-1}$ over the ablation area. Apart from the impact of debris thickness, the glacier tongue of the Batal receives less solar radiation due to the shadow effect of the steep valley margins. Thus ablation is reduced and the vertical gradient of mass balance is attenuated as compared to the open upper part of the glacier. The average value of debris thickness was observed approximately $8 \mathrm{~cm}$ for the entire ablation zone, while it was $18 \mathrm{~cm}$ in the lower ablation zone of the Batal glacier (figure 4). The calculated melt rate in the ablation area of the Batal glacier ranged from a minimum of $2.3 \mathrm{~cm} \mathrm{~d}^{-1}$ to a maximum of $5.8 \mathrm{~cm} \mathrm{~d}^{-1}$. Low melt rates were seen mainly at the lower lateral margin (just above the snout), where the debris cover was thick and continuous, thereby insulating and preserving the underlying ice. High melt rates were observed in two areas. The first one below the icefall with high slope (upper ablation zone), where the debris cover was thin, patchy and full of pebble sized debris, the second near the ice cliff and supra-glacier lakes. Ice cliffs were generally covered with only a thin veneer of debris or dust (Iwata et al. 1980; Sakai et al. 2000), making the sites more vulnerable to surface melting. In addition, the energy absorption at the supra-glacial ponds is several times higher at the surrounding debris-covered surface, resulting in accelerating ice melts (Sakai et al. 2000).

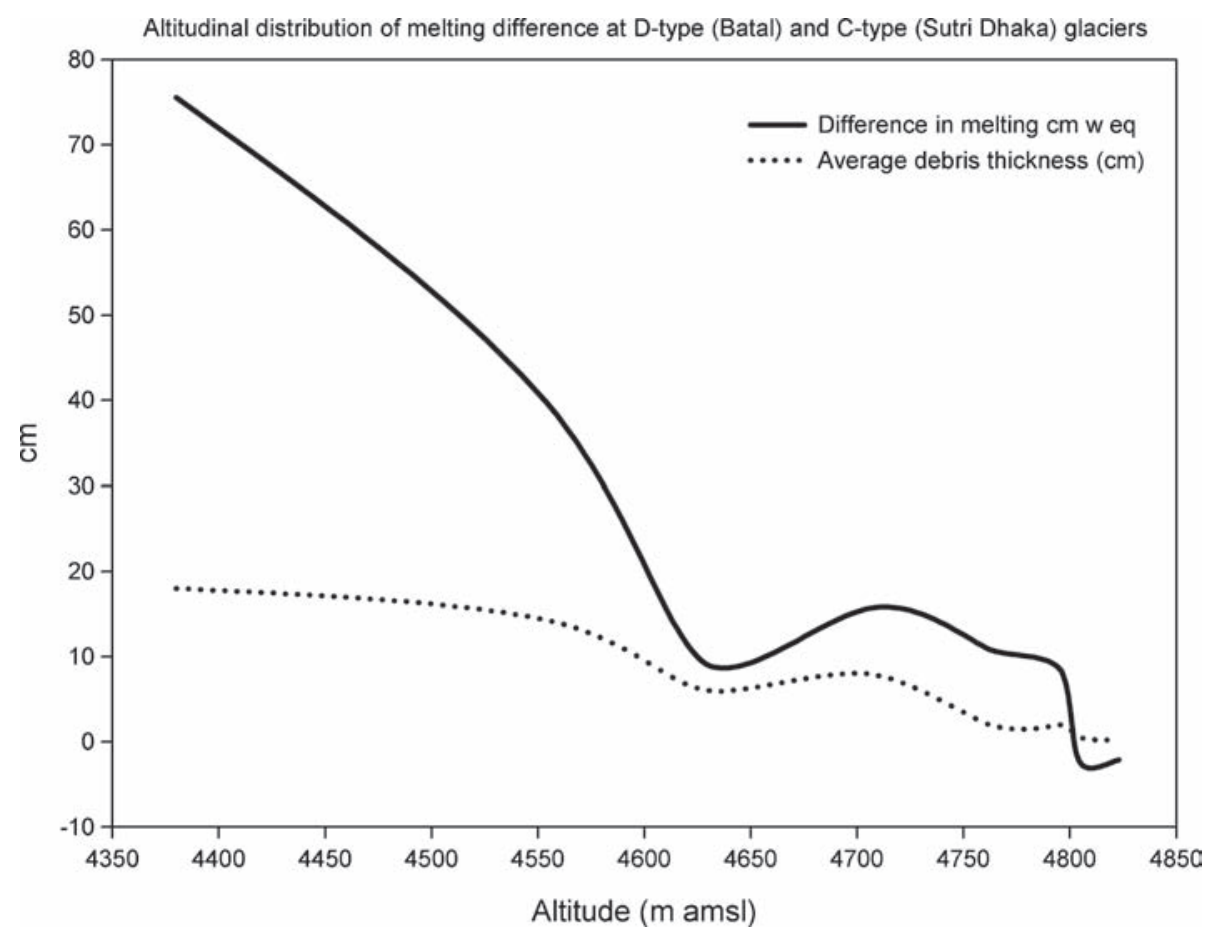

Figure 8. Difference in melting at debris free and debris covered area with varying thicknesses $(0-100 \mathrm{~cm}$; average $0-20 \mathrm{~cm})$ along with altitude. 


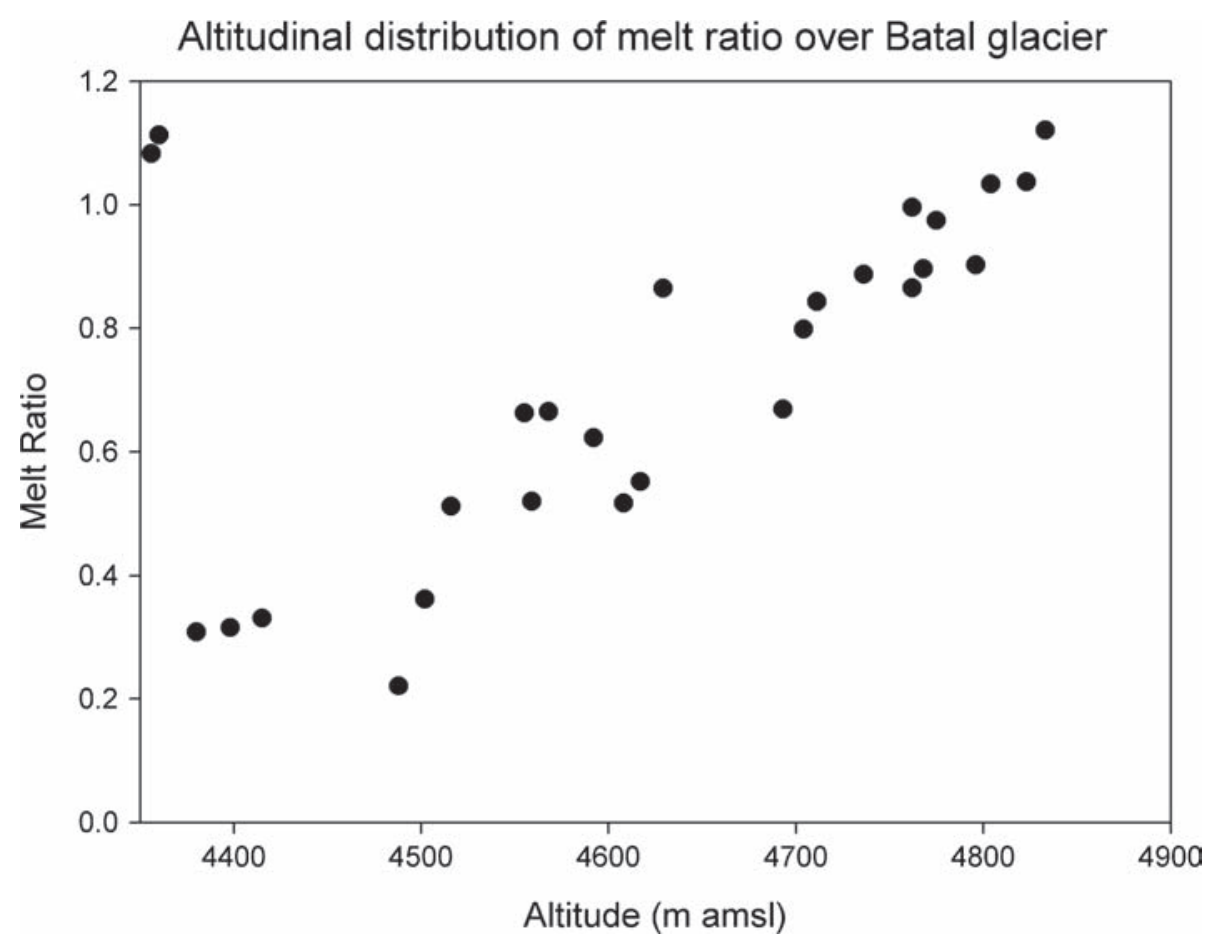

Figure 9. Altitudinal distribution of melt-ratio over the Batal glacier.

Hence, these parts of the glacier are likely to make disproportionately large contributions to ablation; meanwhile, the debris layer becomes increasingly unstable due to the heterogeneous ablation in these parts of the glacier, releasing debris via occasional sluicing of debris down the steep slopes. This process redistributes the debris upon the glacier surface (Iwata et al. 2000; Benn et al. 2001) and then modifies the spatial variability in the ice melt rate. The altitudinal distribution of debris thickness (figure 4) also complicates the ablation gradient in the ablation area, making the comparison with the debris-free ice difficult. The mean ablation gradient for the debris-free ice in case of the Sutri Dhaka glacier, calculated using in situ measurements was $123 \pm 24 \mathrm{~cm}$ we $(100 \mathrm{~m})^{-1}$. In contrast to this, the ablation gradient for the Batal glacier surface was $-92 \pm 18 \mathrm{~cm}$ we $(100 \mathrm{~m})^{-1}$ in the ablation area.

The melt ratio was estimated by the following formula (Qing et al. 2013), defined as the subdebris melt rate, $M$, divided by the bare-ice melt rate at the same elevation, $M^{\prime}$

$$
\text { Melt ratio }=\frac{M}{M^{\prime}} .
$$

A melt ratio of 1.0 indicates that the ice melt rate beneath the debris layer equals that of the bare ice, whereas a ratio $>1.0$ indicates that debris enhances the ice melt rate and a ratio $<1.0$ indicates that the debris inhibits the ice melt (Qing et al. 2013). The spatial distribution of the melt ratio over the Batal glacier (figure 8) clearly demonstrated the crucial effect of debris thickness and its spatial continuity on ice melting in the ablation area. As mentioned above, most of the ablation area has experienced inhibited melting in the Batal glacier, whereas the trend is reversed in the Sutri Dhaka, with most of the ablation area experiencing higher melting. The heterogeneous distribution of debris thickness results in marked spatial variability in the ablation regime on Batal glacier. The graph above (figures 8 and 9) reflects that debris glacier thickness has good control on ablation rate, as thicker debris protect ice surface efficiently from melting. Overall, the debris covered Batal glacier has recorded less ablation rate than the debris-free Sutri Dhaka. For similar elevations, we observed a large difference of mass balance between the Batal and Sutri Dhaka glaciers.

\section{Conclusions}

Two adjoining glaciers Batal and Sutri Dhaka of Chandra basin were monitored during peak ablation period (August-September 2013). The observation revealed that $90 \%$ of the ablation area of Batal glacier was covered by debris ranging between zero and $100 \mathrm{~cm}$ of thickness and described as D-type (debris mantled) glacier. However, the Sutri Dhaka had only $5 \%$ of ablation area which was covered by debris and was called as C-type (debris free) glacier. Even though both the glaciers were located in close proximity, they showed 
contrast results in specific ablation rates. The vertical gradient of the ablation rate showed a positive correlation with the altitude in the Batal (D-type) glacier, while it showed a negatively correlation in the Sutri Dhaka (C-type) glacier. The mean vertical gradient of ablation was negative $(-92 \pm 18 \mathrm{~cm}$ we $\left.100 \mathrm{~m}^{-1}\right)$ in the ablation zone of the Batal glacier, while it was positive $(+123 \pm 24 \mathrm{~cm}$ we $\left.100 \mathrm{~m}^{-1}\right)$ in the Sutri Dhaka. An average ablation

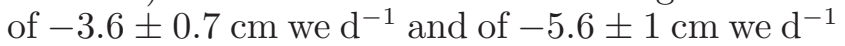
were calculated in the Batal and the Sutri Dhaka glaciers respectively, at approximately $4700 \mathrm{~m}$ amsl. Since, all other climatic variables are similar in both the glaciers, the heterogeneous distribution of debris thickness of the Batal glacier is one of the significant controlling factors of spatial variability of ablation rate of ice. Thicker debris protects ice surface efficiently from melting than thin debris. This study revealed that thick debris cover (debris thickness $>2 \mathrm{~cm}$ ) significantly retards ablation rate of ice and controls specific ablation of glacier. However, more than $10 \mathrm{~cm}$ thickness of debris cover in the Batal glacier has attenuated melting rates up to $70 \%$ of the total melting. The calculated average melt ratio of Batal glacier is $<1$, indicating that debris cover attenuated the ice melt throughout the ablation zone and about $90 \%$ of the ablation area experienced inhibited melting in this glacier. Debris mantled glacier Batal showed a $373 \pm 33.5 \mathrm{~m}$ (an average of $7.3 \pm 0.7 \mathrm{~m} \mathrm{a}^{-1}$ ) terminal recession during 1962-2013, while C-type glacier, the Sutri Dhaka experienced $579 \pm 33.5 \mathrm{~m}$ (an average of $11.4 \pm 0.7 \mathrm{~m} \mathrm{a}^{-1}$ ) for the same period. Thick debris cover area over the Batal glacier reduced terminal recession by $41 \%$ during 2000-2013, however, for the clean glacier Sutri Dhaka terminal recession increased by $35 \%$ during same period. Apart from other factors, the areal coverage and thickness of debris have also a significant control on the recession rate of lower terminus. As shown by Bolch et al. (2011), Himalayan glaciers are losing significant ice mass in recent decades due to extensive debris cover. Contrastingly, this study reveals that extensive debris cover area with $>2 \mathrm{~cm}$ thickness retard the mass loss of ice in Himalayan glaciers.

\section{Acknowledgements}

This work has been funded by National Centre for Antarctic and Ocean Research, Ministry of Earth Sciences, Government of India, under the program 'Cryosphere and Climate'. We heartily acknowledge and thank to Dr Shailesh Nayak, Secretary, ESSO-MoES for his support to run the field expedition and giving valuable scientific suggestions for improving the quality of the paper. We also thank Dr S Rajan, Director, ESSO-NCAOR for his unconditional support. We thank the National Remote Sensing Centre (NRSC) and the United State Geological Survey (USGS) for providing satellite data and Survey of India for providing the toposheets for our study area. We thank our field assistant, Mr B B Adhikari and the porters who were involved in our field trips, and ABVIMAS, Manali for providing some of the facilities to carry out this work. We are also thankful to IITM, Pune for facilitating necessary instruments that enabled us to collect meteorological data during the field.

\section{References}

Aniya M, Sato H, Naruse R, Skvarca P and Casassa G 1996 The use of satellite and airborne imagery to inventory outlet glaciers of the Southern Patagonia Icefield, South America; Photogramm. Engg. Remote Sens. 62 13611369.

ASTER GDEM Validation Team ASTER Global Digital Elevation Model Version 2 - Summary of Validation Results; http://www.ersdac.or.jp/GDEM/ver2Validation/ Summary_GDEM2_validation_report_final.pdf2011.

Azam M F, Wagnon P, Ramanathan A, Vincent C, Sharma P, Arnaud Y, Linda A, Pottakkal J G, Chevallier P, Singh V B and Berthier E 2011 From balance to imbalance: A shift in the dynamic behaviour of Chhota Shigri Glacier (western Himalaya, India); J. Glaciol. 58 315-324, doi: 10.3189/2012JoG11J123.

Bhambri Rakesh, Tobias Bolch and Ravinder Kumar Chaujar 2012 Frontal recession of Gangotri Glacier, Garhwal Himalayas, from 1965 to 2006, measured through high-resolution remote sensing data. Curr. Sci. 102 489-494.

Barnett T P, Adam J C and Lettenmaier D P 2005 Potential impacts of a warming climate on water availability in snow dominated regions; Nature 438 303-309, doi: 10.1038 /nature04141.

Basnett S, Kulkarni A V and Bolch T 2013 The influence of debris cover and glacial lakes on the recession of glaciers in Sikkim Himalaya, India; J. Glaciol. 59 1035-1046, doi: 10.3189/2013JoG12J184.

Benn D I and Owen L A 2002 Himalayan glacial sedimentary environments: A framework for reconstructing and dating the former extent of glaciers in high mountains; Quant. Int. 97-98 3-25, doi: 10.1016/S1040-6182(02)00048-4.

Benn D I, Wiseman S and Hands K A 2001 Growth and drainage of supra-glacial lakes on the debris-mantled Ngozumpa Glacier, Khumbu Himal, Nepal; J. Glaciol. 47 626-638, doi: 10.3189/172756501781831729.

Bhargava and Srivastava 1982 Unpublished GSI Report of Field Season 1981-82

Bishop M P, Bonk R, Kamp U and Shroder Jr J F 2001 Terrain analysis and data modeling for alpine glacier mapping; Polar Geographys. 25 182-201, doi: 10.1080/10889 370109377712.

Bolch T, Buchroithner M, Pieczonka T and Kunert A 2008 Planimetric and volumetric glacier changes in the Khumbu Himalaya, Nepal, since 1962 using Corona, Landsat TM and ASTER data; J. Glaciol. 54 592-600, doi: 10.3189/002214308786570782.

Bolch T, Pieczonka T and Benn D I 2011 Multi-decadal mass loss of glaciers in the Everest area (Nepal Himalaya) derived from stereo imagery; The Cryosphere 5 349-358, doi: 10.5194/tc-5-349-2011. 
Bookhagen B and Burbank D W 2006 Topography, relief and TRMM-derived rainfall variations along the Himalaya; Geophys. Res. Lett. 33 L08405, doi: 10.1029/2006GL026037.

Brock B, Rivera A, Casassa G, Bown F and Acuna C 2007 The surface energy balance of an active ice-covered volcano: Villarrica Volcano, southern Chile; Ann. Glaciol. 45(1) 104-114, doi: 10.3189/172756407782282372.

Buchroithner M F and Bolch T 2007 An automated method to delineate the ice extension of the debris-covered glaciers at Mt Everest based on ASTER imagery; Grazer Schr. Geogr. Raumforsch. 43 71-78.

Burbank D W 1982 Correlations of climate, mass balances, and glacial fluctuations at Mount rainer, Washington, USA, since 1850; Arctic and Alpine Res. 14(2) 137-148.

Dobhal D P, Gergan J T and Thayyen R J 2004 Recession and morphometrical change of Dokriani Glacier (1962-1995), Garhwal Himalaya, India; Curr. Sci. 86(5) 692-696.

Dobhal D P, Gergan J T and Thayyen R J 2008 Mass balance studies of the Dokriani Glacier from 1992 to 2000, Garhwal Himalaya, India; Bull. Glacier Res. 25 9-17.

Dobhal D P, Mehta M and Srivastava D 2013 Influence of debris cover on terminus retreat and mass changes of Chorabari Glacier, Garhwal region, central Himalaya, India; J. Glaciol. 59(217) 961-971, doi: 10.3189/2013JoG12J180.

Dyurgerov M B and Meier M F 2005 Glaciers and the changing Earth system: A 2004 snapshot; Boulder, CO, Institute of Arctic and Alpine Research, Occasional Paper 58.

Foster L A 2010 Utilisation of remote sensing for the study of debris covered glaciers: Development and testing of techniques on Miage Glacier, Italian Alps, PhD Thesis, School of Social and Environmental Science, University of Dundee.

Gratton D J, Howarth P J and Marceau D J 1990 Combining DEM parameters with Landsat MSS and TM imagery in a GIS for mountain glacier characterization; IEEE Trans. Geosci. Remote Sens. 28 766769.

Hall Dorothy K, Klaus Bayr J, Wolfgang Schöner, Robert A Bindschadler and Janet Y L Chien 2003 Consideration of the errors inherent in mapping historical glacier positions in Austria from the ground and space (1893-2001); Remote Sens. Environ. 86 566-577, doi: 10.1016/S0034-4257(03)00134-2.

Harrison W D, Elsberg D H, Cox L H and March R S 2005 Different mass balances for climatic and hydrologic applications; J. Glaciol. 51(172) 176, doi: 10.3189/1727564 09787769654.

IPCC 2007 Climate Change 2007 - The Physical Science Basis, Cambridge University Press.

Iwata S, Tatsuto A, Tsutomu K, Katsumoto S and Satoru Y 2000 Morphological evolution of the debris cover on Khumbu Glacier, Nepal, between 1978 and 1995; IAHS Publ. 264 3-11.

Iwata S, Watanabe O and Fushimi H 1980 Surface morphology in the ablation area of the Khumbu glacier, Seppyo; J. Japan Soc. Snow Ice, Spec. Issue 41 9-17.

Jansson P 1999 Effect of uncertainties in measured variables on the calculated mass balance of Storglaciären; Geogr. Ann. 81A(4) 633-642, doi: 10.1111/1468-0459.00091.

Kamp U, Byrne M and Bolch T 2011 Mapping glacier fluctuations between 1975 and 2008 in the Greater Himalaya range of Ladakh, north-western India; Int. J. Mt. Sci. 8(3) 374-389, doi: 10.1007/s11629-011-2007-9.

Kaser G 2001 Glacier-climate interaction at low latitudes; J. Glaciol. 47(157) 195-204, doi: 10.3189/17275650178 1832296.
Konovalov V 2000 Computations of melting under moraine as a part of regional modelling of glacier runoff, debriscovered glaciers; Proceedings of a Workshop held at Seattle, Washington, USA, September 2000, IAHS Publ. no. 264, Quat. Int. 97-98 3-25.

Kulkarni A V, Bahuguna I M, Rathore B P, Singh S K, Randhawa S S, Sood R K and Dhar S 2007 Glacial retreat in Himalaya using Indian Remote Sensing satellite data; Curr. Sci. 92(1) 69-74.

Kulkarni A V, Rathore B P, Mahajan S and Mathur P 2005 Alarming retreat of Parbati glacier, Beas basin, Himachal Pradesh; Curr. Sci. 88(11) 1844-1850.

Mehta M, Dobhal D P and Bisht M P S 2011 Change of Tipra Glacier in the Garhwal Himalaya, India Between 1962 and 2008; Prog. Phys. Geog. 35(6) 721-738, doi: 10.1177/0309133311411760.

Mehta M, Dobhal D P, Pratap B, Verma A, Kumar A and Srivastava D 2013 Glacier changes in Upper Tons River basin, Garhwal Himalaya, Uttarakhand, India; Zeitschrift für Geomorphologie 57(2) 225-244, doi: 10.1127/0372-8854/2012/0095.

Mihalcea C, Brock B W, Diolaiuti G, Agata C D, Citterio M, Kirkbride M P, Cutler M E J and Smiraglia C 2008 Using ASTER satellite and ground-based surface temperature measurements to derive supraglacial debris cover and thickness patterns on Miage Glacier (Mont Blanc Massif, Italy); Cold Regions Sci. Tech. 52 341-354, doi: 10.1016/j.coldregions.2007.03.004.

Negi H S, Saravana G, Rout R and Snehmani 2013 Monitoring of great Himalayan glaciers in Patsio region, India using remote sensing and climatic observations; Curr. Sci. 105(10) 1383-1392.

Ogilvie I H 1904 The effect of superglacial débris on the advance and retreat of some Canadian glaciers; J. Geol. 12(8) $722-743$.

Østrem G 1959 Ice melting under a thin layer of moraine, and the existence of ice cores in moraine ridges; Geogr. Ann. 41(4) 228-230.

Østrem G and Brugman M 1991 Glacier mass-balance measurements: A manual for field and office work; NHRI Science Report 4, National Hydrology Research Institute, Environment Canada, Saskatoon, Sask.

Pandey P and Venkataraman G 2013 Changes in the glaciers of Chandra-Bhaga basin, Himachal Himalaya, India, between 1980 and 2010 measured using remote sensing; Int. J. Remote Sens. 34(15) 5584-5597, doi: 10.1080/01431161.2013.793464.

Pandey P, Kulkarni A V and Venkataraman G 2013 Remote sensing study of snowline altitude at the end of melting season, Chandra-Bhaga basin, Himachal Pradesh, 1980-2007; Geocarto Int. 28(4) 311-322, doi: 10.1080/10106049.2012.705336.

Pandey A C, Gosh S and Nathawat M S 2011 Evaluating patterns of temporal glacier changes in Greater Himalayan Range, Jammu and Kashmir, India; Geocarto Int. 26(4) 321-338, doi: 10.1080/10106049.2011.554611.

Parasher K C 1990 Unpublished GSI Report of Field Season 1989-90.

Parasher K C and Raj D 1988 Unpublished GSI Report of Field Season 1987-88.

Parasher K C and Rapa D A 1981 Unpublished GSI Report of Field Season 1980-81.

Paterson W S B 1994 The physics of glaciers 3rd edn, Elsevier, Oxford.

Paul F, Barry R G, Cogley J G, Frey H, Haeberli W, Ohmura A, Ommanney C S L, Raup B, Rivera A and Zemp M 2009 Recommendations for the compilation of glacier inventory data from digital sources; Ann. Glaciol. 50 119-126. 
Paul F, Huggel C and Kääb A 2004 Combining satellite multispectral image data and a digital elevation model for mapping debris-covered glaciers; Remote. Sens. Environ. 89 510-518, doi: 10.1016/j.rse.2003.11.007.

Porter S C 1981 Recent glacier variations and volcanic eruptions; Nature 291 139-142, doi: 10.1038/291139a0.

Qing K C, Cheng K, Ralf L and Xiang Q 2013 Glacier velocity measurements in the eastern Yigong Zangbo basin, Tibet, China; J. Glaciol. 59(218) 1060-1068, doi: 10.3189/2013JoG12J234.

Rabatel A, Dedieu J P and Vincent C 2005 Using remote sensing data to determine equilibrium-line altitude and mass balance time series: Validation on three French glaciers, 1994-2002; J. Glaciol. 51(175) 539-546, doi: 10.3189/172756505781829106.

Racoviteanu A E, Arnaud Y, Williams M W and Ordon J 2008 Decadal changes in glacier parameters in the Cordillera Blanca, Peru, derived from remote sensing; J. Glaciol. 54(186) 499-510, doi: $10.3189 / 002214308785836922$.

Rai S C and Gurung A 2005 Raising awareness of the impacts of climate change: Initial steps in shaping policy in Nepal; Mt. Res. Dev. 25(4) 316-320, doi: 10.1659/0276-4741(2005)025[0316:RAOTIO]2.0.CO;2.

Raina V K 2009 Himalayan glaciers - behaviour and climate change: Himalayan glaciers - a state-of-art review of glacial studies, glacial retreat and climate change; Moef discussion paper, G.B. Pant institute of Himalayan Environment and Development, Kosi-Katarmal, Almora, Uttarkhand.

Raina V K and Srivastava D 2008 Glacier Atlas of India; Geological Society of India, Bangalore.

Reid T D and Brock B W 2010 An energy-balance model for debris-covered glaciers including heat conduction through the debris layer; J. Glaciol. 56(199) 903-916, doi: $10.3189 / 002214310794457218$.

Sakai A, Takeuchi N, Fujita K and Nakawo M 2000 Role of supraglacial ponds in the ablation process of a debriscovered glacier in the Nepal Himalayas; Symposium at Seattle 2000 - Debris-Covered Glaciers, IAHS Publ. 264 119-130.

Sangewar C V and Shukla S P 2009 Inventory of the Himalayan glaciers: A contribution to the international hydrological programme; Spec. Publ. No. 34, Geological Survey of India.

Scherler D, Bookhagen B and Strecker M R 2011 Spatially variable response of Himalayan glaciers to climate change affected by debris cover; Nat. Geosci. 4 156-159, doi: 10.1038/ngeo1068.

Sharma P 2007 Mass balance and chemical characteristics of Chhota Shigri Glacier-B, Lahaul-Spiti Valley, Himachal
Pradesh; Ph.D thesis, School of Environmental Sciences, Jawaharlal Nehru University, New Delhi.

Sharma S S and Ganju A 2000 Complexities of avalanche forecasting in Western Himalaya - An overview; Cold Reg. Sci. Technol. 31(2) 95-102, doi: 10.1016/S0165232X(99)00034-8.

Shukla A, Gupta R P and Arora M K 2009 Estimation of debris cover and its temporal variation using optical satellite sensor data: A case study in Chenab basin, Himalaya; J. Glaciol. 55(191) 444-452, doi: 10.3189/002214309788816632.

Sidjak R W and Wheate R D 1999 Glacier mapping of the Illecillewaet icefield, British Columbia, Canada, using Landsat TM and digital elevation data; Int. J. Remote Sens. 20 273-284.

Takeuchi Y, Kayastha R B and Nakawo M 2000 Characteristics of ablation and heat balance in debris-free and debriscovered areas on Khumbu Glacier, Nepal Himalayas in the pre-monsoon season; Symposium at Seattle $2000-$ Debris-Covered Glaciers, IAHS Publ. 264 53-61.

Taschner S and Ranzi R 2002 Comparing the opportunities of Landsat-TM and ASTER data for monitoring a debriscovered glacier in the Italian Alps within the GLIMS project; In: 22nd International Geoscience and Remote Sensing Symposium (IGARSS 2002), 24-28 June 2002, Toronto, Canada. Proceedings, Institute of Electrical and Electronics Engineers, Piscataway, NJ, 2 10441046.

Vincent C, Ramanathan A L, Wagnon P, Dobhal D P, Linda A, Berthier E, Sharma P, Arnaud Y, Azam M F, Jose P G and Gardelle J 2013 Balanced conditions or slight mass gain of glaciers in the Lahaul and Spiti region (northern India, Himalaya) during the nineties preceded recent mass loss; Cryosphere 7(2) 569-582, doi: 10.5194/tc-7-569-2013.

Wagnon P, Linda A, Arnaud Y, Kumar R, Sharma P, Vincent C, Pottakkal J G, Berthier E, Ramanathan A L, Hasnain S I and Chevallier P 2007 Four years of mass balance on Chhota Shigri glacier, Himachal Pradesh, India: A new benchmark glacier in the western Himalaya; $J$. Glaciol. 53(183) 603-611, doi: 10.3189/00221430778440 9306.

Wagnon P, Ribstein P, Kaser G and Berton P 1999 Energy balance and runoff seasonality of a Bolivian glacier; Global Planet. Change 22(1-4) 49-58, doi: 10.1016/S0921-8181(99)00025-9.

Worni R, Huggel C and Stoffel M 2013 Glacial lakes in the Indian Himalayas - From an area-wide glacial lake inventory to on-site and modeling based risk assessment of critical glacial lakes; Sci. Total Environ. 468-469 S71-84, doi: $10.1016 /$ j.scitotenv.2012.11.043. 